Весна Дицков

Универзитет у Београду

Филолошки факултет

vesna.dickov@fil.bg.ac.rs

821.134(82).09 Борхес Л. Х.
https://doi.org/10.18485/ai_san_o gradu.2018.ch16

\title{
БУЕНОС АЈРЕС У ПОЕЗИЈИ \\ ХОРХЕА ЛУИСА БОРХЕСА: „БУЕНОСАЈРЕСКА ТРИЛОГИЈА“ (1923-1929)
}

Овај рад се бави тумачењем присуства Буенос Ајреса у раној етапи Борхесовог песничког стваралаштва, када је током треће деценије XX века настала такозвана „буеносајреска трилогија“, састављена од прве три Борхесове збирке песама: Оgушевленье Буенос Ајресом, Месеи оg ирекойуйа и Свеска Сан Марйин. Сагледава се место и значај главног града Аргентине, његових предграђа, улица, тргова и паркова у поменутим збиркама Хорхеа Луиса Борхеса, са циљем да се одреди улога Буенос Ајреса у Борхесовој уметничкој идентификацији као изразито урбаног песника.

Кључне речи: хиспаноамеричка поезија, Хорхе Луис Борхес, Буенос Ајрес, град, ултраизам.

Песничко стваралаштво заузима истакнуто место у целокупном опусу Хорхеа Луиса Борхеса (Jorge Luis Borges, 1899-1986), нарочито је обележило његове литерарне почетке, када се руковођен књижевно-естетичким начелима авангардних покрета бавио превасходно поезијом све до тридесетих година XX столећа. Једна од доминантних тема Борхесовог песништва је његов родни град Буенос Ајрес који се, поред тога што је представљао неисцрпан извор песниковог надахнућа, често трансформисао у непосредни подстицај за 
интензивна метафизичка промишљања о људској егзистенцији и универзуму.

Током боравка у Шпанији (1919-1921), Борхес се упознао са европским авангардним стремљењима, која су усмерила његове почетне кораке на пољу књижевног стваралаштва како у погледу бујања особеног креативног набоја тако и у погледу развоја јасно дефинисане теоријске мисли. Сјединивши ултраистичку ${ }^{1}$ технику (пластичне метафоре, концизност), те интензитет у изразу својствен експресионистима са ритмом и жудњом преузетим из својих првих витмановских стихова ${ }^{2}$, Борхес се, по угледу на футуристе, обраћао првенствено урбаној публици, користећи обилато аутономне слике, које су захваљујући креационистима ${ }^{3}$

1 Ултраизам (шп. ultraísmo) је назив једног од водећих шпанских авангардних књижевних покрета; појавио се крајем двадесетих година прошлог века под утицајем других авангардних токова, првенствено хиспаноамеричког креационизма и различитих покрета европског порекла - футуризма, дадаизма, експресионизма и кубизма; трајао је у пуној афирмацији као један од доминантних авангардних токова до средине треће деценије XX столећа (1919-1923), када његов утицај почиње да јењава прво у Шпанији, а потом и у Хиспанској Америци. Будући да се деловање ултраиста односило искључиво на обнову поезије, покрет није изазивао свеопшту пажњу шире читалачке публике, али је међу песницима био изузетно присутан и уважаван.

2 Своју прву песму “Нimno al mar” („Химна мору“), коју је написао под утицајем Волта Витмена, Борхес је објавио 31. децембра 1919. године у часопису Гресиа (Grecia).

3 Креационизам (шп. creacionismo) је био први авангардни покрет који се јавио у Хиспанској Америци; настао је у другој деценији XX века, као производ тежње младих песника на челу са Чилеанцем Висентеом Уидобром (Vicente Huidobro) да се сваком аутору подари апсолутна стваралачка слобода у креирању нове, властите стварности, независне од спољашње, појавне стварности. По окончању Првог светског рата, креационизам је стекао велику популарност и у Шпанији, где је утицао на формирање другог авангардног правца - ултраизма. 
постале независне у односу на спољашњу стварност, са циљем да проникне у суштину осећаја, односно, у срж унутрашње стварности, без описивања просторних и/ или темпоралних околности (Artundo 1999: 70-71). Посебно снажан утисак на Борхеса је оставио ултраизам, чија су естетичка начела (честа употреба метафора, одбацивање визуелних поређења, изостављање риме) представљала значајан отклон у односу на, до тада, доминантну поетику модернизма. По повратку (1921) из Шпаније, Борхес преноси ултраизам у Буенос Ајрес, уз неопходна усклађивања основних поставки овог авангардног покрета са непосредним околностима својственим аргентинском поднебљу. Са појавом књижевне групе Мартин Фјеро $^{4}$ која се у духу креолизма ${ }^{5}$ залагала за јачање националног и културног идентитета а на формалном плану је подстицала уважавање авангардних поетских назора, Борхесов песнички израз почиње да превазилази уобичајене ултраистичке оквире и налази одговарајући лирски одраз у „буеносајреској трилогији“ (“trilogía porteña”) која обухвата прве три збирке песама овог аргентинског аутора, настале током треће деценије XX века: Ogyшевљене Буе-

4 Мартин Фјеро (шп. Martín Fierro) је била аргентинска, авангардна група, оформљена у Буенос Ајресу средином треће деценије XX века; названа по истоименом часопису (Martín Fierro, 1924-1927), трајала је десетак година (1924-1935); убрзо по оснивању привукла је велики број присталица целовитим естетичким програмом који се заснивао на тековинама ултраизма и књижевног американизма.

5 Креолизам (шп. criollismo) је назив књижевног покрета који се појавио крајем XIX века, тј. у време експанзије политичке независности хиспаноамеричких земаља, тек ослобођених колонијалних стега и вишевековне шпанске хегемоније; основни циљ овог покрета је било стицање и јачање сопственог културног идентитета, уобличеног поглавито у руралним пределима и без уплива европских утицаја. 
нос Ајресом (Fervor de Buenos Aires, 1923), Месеи, og üpeкойуйа (Luna de enfrente, 1925) и Свеска Сан Марӣин (Cuaderno San Martín, 1929).

Прву збирку песама Борхес је посветио средини из које је потекао, доделивши јој индикативан наслов Оgушевљење Буенос Ајресом. У предговору, који је написао 1969. године приликом ревизије првобитног рукописа насталог током 1921. и 1922. године, Борхес истиче да је у збирци Оgушевтьеье Буенос Ајресом унапред предочено све оно чиме се потом у књижевности бавио, с том разликом што су га као младића највише привлачили залазак сунца, предграђа и беда, док су у зрело доба његови приоритети постали јутро, центар града и спокојство (Borges 1974: 13).

Збирка Ояушевљене Буенос Ајресом се састоји од тридесет три песме написане у слободном стиху које - по оцени Љиљане Павловић-Самуровић (1993: 319) - одликује авангардни стил богат новим метафорама и тематика везана за простор и атмосферу ауторовог родног града. Иновације у овој збирци односе се на садржину песама и њихова стилска својства. Борхес није прихватао извесну безличност коју је наметао ултраизам јер је сматрао да је свако књижевно дело у бити аутобиографског карактера, нити је заступао идеју да метафора представља језгро књижевног језика, верујући да ова стилска фигура проистиче из личног искуства онога ко је створио (Zonana 1999: 305). Буенос Ajpec је за време Борхесовог трогодишњег боравка у Шпанији израстао у динамичну, космополитску престоницу, али Борхес није задивљен бучним авенијама са модерним грађевинама, већ у својим дугим шетњама залази у мирна, радничка предграђа са погледом на пространства пампе, чија свакодневица буди у њему најдубље метафизичке немире (Videla 1971: 149), као на пример у песми „Свануће“ (“Amanecer”): 
EN LA HONDA noche universal que apenas contradicen los faroles una racha perdida ha ofendido las calles taciturnas como presentimiento tembloroso del amanecer horrible que ronda los arrabales desmantelados del mundo. Curioso de la sombra y acobardado por la amenaza del alba reviví la tremenda conjetura de Schopenhauer y de Berkeley que declara que el mundo es una actividad de la mente, un sueño de las almas, sin base ni propósito ni volumen. $Y$ ya que las ideas no son eternas como el mármol sino inmortales como un bosque o un río, la doctrina anterior asumió otra forma en el alba y la superstición de esa hora cuando la luz como una enredadera va a implicar las paredes de la sombra, doblegó mi razón y trazó el capricho siguiente: si están ajenas de sustancia las cosas y si esta numerosa Buenos Aires no es más que un sueño que erigen en compartida magia las almas, hay un instante en que peligra desaforadamente su ser $y$ es el instante estremecido del alba, cuando son pocos los que sueñan el mundo y sólo algunos trasnochadores conservan, 
cenicienta y apenas bosquejada,

la imagen de las calles

que definirán después con los otros. ${ }^{6}$

(Borges 1974: 38)

Истражујући мање познате, радничке делове Буенос Аjpeca, Борхес је залазио у удаљене градске четврти, где је посматрајући зграде, дворишта и улице проналазио инспирацију за стварање песничких творевина изузетне уметничке вредности. У свим својим визијама Борхес је настојао да истакне духовност која извире из улица Буенос Аjpeca, а измештање појавног у психолошко - сматра Виктор Густаво Сонана (Zonana 1999: 310) - омогућавало му је да оствари процес интероризације ових градских простора, као, на пример, у песми „Улице“("Las calles”), првој по редоследу из збирке Ogушевљене Буенос Ајресом, коју поносно започиње метафоричком синтезом материјалног и духовног:

6 „У дубокој општој ноћи, / коју једва оповргавају светиљке / залутали налет ветра / увредио је ћутљиве улице / као уздрхтало предосећање / грозног сванућа које тумара / запуштеним предграђима света. / Радознало загледан у таму / и престрашен претњом свитања / доживео сам страховиту претпоставку / Шопенхауера и Берклија / који тврде да је свет / делатност духа, / сан душа / без основе, намере и просторности. / А како идеје / нису вечне као мермер, / већ бесмртне као шума или река, / раније учење / добило је у зору други облик, / а празноверје тог тренутка, / када се светлост попут ладолежа / пуже по зидовима таме, / преварило ми је разум / и нацртало овај капричо: / Ако ствари немају материјалност / и ако је многољудни Буенос Ajpec / само сан / који сањају душе у заједничкој опчињености / има тренутак / када је његово биће у великој опасности, / а то је дрхтави тренутак сванућа, / када мало њих сања свет / и само неколико ноћника чувају, / пепељасту и тек скицирану, / слику улица / коју ће касније са другима довршити. " (Превео са шпанског Радивоје Константиновић.) (Борхес 1992: 133-134) 
Las calles de Buenos Aires

ya son mi entraña.

No las ávidas calles,

incómodas de turba y de ajetreo,

sino las calles desganadas del barrio,

casi invisibles de habituales,

enternecidas de penumbra - y de ocaso

$y$ aquellas más afuera

ajenas de árboles piadosos

donde austeras casitas apenas se aventuran,

abrumadas por inmortales distancias,

a perderse en la honda visión

de cielo y de llanura.

Son para el solitario una promesa

porque millares de almas singulares las pueblan,

únicas ante Dios y en el tiempo

$y \sin$ duda preciosas.

Hacia el Oeste, El Norte y el Sur

se han desplegado - y son también la patria - las calles;

ojalá en los versos que trazo

estén sus banderas. ${ }^{7}$

(Borges 1974: 17)

Ова песма може да представља виђење било

7 „Улице Буенос Ајреса / већ су моја утроба. / Не похлепне улице, / неугодне због светине и замора од сувишног ходања, / већ омражене улице из предграђа, / скоро уобичајено невидљиве, / умекшане полутамом - и заласком сунца / и оне удаљеније / без милостивог дрвећа / где се једноставне кућице једва усуђују, / оптерећене бесмртним удаљеностима / да се изгубе у дубокој визији / неба и равнице. / Оне су за усамљеника обећање / јер их настањују хиљаде изванредних душа / јединствених пред Богом и у времену / и без сумње драгоцених. / Према Западу, Северу и Југу / рашириле су се - и такође су отаџбина - улице; / дабогда у стиховима које пишем / буду њихове заставе.“ (Превела са шпанског Весна Дицков.) 
којег грађанина Буенос Ајреса, везујући се за његово сопствено „ја“, као и за његово властито време (Dante Cincotta 2005: 233).

Заинтересованост младог Борхеса за ободне, рустичне делове родног града у којима настоји да открије, упркос њиховој патетичности, изворну лепоту и аутентичан дух аргентинске престонице, независтан од европских културолошких уплива, развила се под утицајем песника Евариста Карјега ${ }^{8}$ и Маседонија Фернандеса'; подстакнут ентузијазмом проистеклим из својеврсне личне побуне, општеприсутним креолистичким идејама и пробуђеним песничким инстинктом, Борхес је створио нову естетику овог, до тада у аргентинској поезији углавном занемариваног, градског пејзажа (Zito 1999: 111). У стиховима обухваћеним збирком Оgушевљене Буенос Ајресом опеване су омиљене песникове дестинације у родном граду, било да је реч о знаменитим местима од великог историјског и културног значаја којима је Борхес посветио песме насловљене по угледу на њихове званичне називе, било

8 Еваристо Карјего (Evaristo Carriego, 1883-1912) је био аргентински модернистички песник; објавио је само једну збирку песама Misas herejes (Jерейичке мисе, 1908) у којој се налазе сабране његове творевине у стиху посвећене забаченим, сиромашним предграђима Буенос Ајреса. Ово дело, чији је један примерак Карјего поклонио Борхесовом оцу, Хорхе Луис је често ишчитавао током свог боравка у Женеви (1914-1919).

9 Маседонио Фернандес (Macedonio Fernández, 1874-1952), један од претеча авангарде у Хиспанској Америци, створио је сопствену поетику - „поематика Мишљења (poemática del Pensar) желећи да пише песничка дела пуна смисла која ће одразити не само осећајни, већ и мисаони вид његове личности (PavlovćSamurović 1993: 382). Борхес га је познавао од детињства, јер је Фернандес често посећивао његовог оца, а по повратку из Европе (1921) открио је и његово стваралаштво, те су заједно - са песником Рикардом Гвиралдесом (Ricardo Güiraldes) - ocновали (1922) књижевни часопис Проа (Proa). 
да се ради о неугледним, забаченим, безименим уличицама на периферији Буенос Ајреса. Тако, на пример, у песми „Трг Свети Мартин“ (“La plaza San Martín”), посвећеној Маседонију Фернандесу, поменути трг, који краси једна од најлепших зелених јавних површина у Буенос Ајресу, током поподневне шетње пред Борхесом „се отвара као смрт, као сан“ (“se abre como la muerte, como el sueño”), а у песми „Ла Реколета“"("La Recoleta”) посета породичној гробници за коју каже да је „место његовог пепела“ (“el lugar de mi ceniza”) ${ }^{10}$, наводи аутора на размишљања о метафизичким темама (смисао живота и његова неумитна пролазност, простор, време, смрт), подстичући га да инкорпорира мотиве (мачеви, огледала) којима ће се често враћати током читавог свог књижевног стваралаштва:

Vibrante en las espadas y en la pasión

$y$ dormida en la hiedra, sólo la vida existe.

El espacio y el tiempo son normas suyas, son instrumentos mágicos del alma,

y cuando ésta se apague, se apagarán con ella el espacio, el tiempo y la muerte, como al cesar la luz caduca el simulacro de los espejos que ya la tarde fue apagando. ${ }^{11}$

(Borges 1974: 18)

10 Борхес је преминуо 14. јуна 1986. године у Женеви, где је, по сопственој жељи, и сахрањен на гробљу Пленпале (Plainpalais).

11 „Устрептао у мачевима и страсти / и уснуо у бршљану, / само живот постоји. / Простор и време су његова начела, / то су магични инструменти душе, / а када се она угаси, / угасиће се са њом простор, време и смрт, / као што са нестанком светла / престаје привид са огледала / које већ увече се гаси." (Превела са шпанског Весна Дицков.) 
Поред централних делова Буенос Ајреса одакле је потицао, Борхес је у својим двадесетим годинама откривао, пасионирано сатима шетајући родним градом, скривену лепоту његових предграђа. У песми „Непозната улица“ (“Calle desconocida”) описује једно од таквих искустава које је стекао док је у смирај дана корачао малом, периферном улицом; користећи хипалаге („племенита ширина терасе“ ["noble anchura de terraza”]), пластичне метафоре и поређења у дескрипцији овог урбаног пејзажа, Борхес исказује сопствена егзистенцијалистичка промишљања:

Quizá esa hora de la tarde de plata

diera su ternura a la calle,

haciéndola tan real como un verso

olvidado y recuperado.

Sólo después reflexioné

que aquella calle de la tarde era ajena,

que toda casa es un candelabro

donde las vidas de los hombres arden

como velas aisladas,

que todo inmediato paso nuestro

camina sobre Gólgotas. ${ }^{12}$

(Borges 1974: 20)

Борхес је још у својим младим данима открио истинску припадност аргентинском тлу кроз нераски-

12 „Можда је овај тренутак сребрног сутона / пренео своју нежност на ову улицу / учинивши је стварном као стих / заборављен и поново нађен. / Тек касније сам схватио / да је та улица туђа, / да је свака кућа велики свећњак / у коме животи људи горе / као усамљене свеће, / да сваки наш непромишљени корак / пролази глоготама.“ (Превео са шпанског Радивоје Константиновић.) (Борхес 1992: 131) 
диву повезаност са родним градом, који ће му до краја живота остати непресушан извор песничког надахнућа, о чему сведоче и стихови из песме „Предграђе“ (“Arrabal”), симболично посвећене шпанском песнику Гиљерму де Тореу ${ }^{13}$. У овој творевини Борхес изражава не само свој однос према животу, већ и ватрену, бесконачну потрагу за временом (Dante Cincotta 2005: 238):

Esta ciudad que yo creí mi pasado

es mi porvenir, mi presente;

los años que he vivido en Europa son ilusorios, yo estaba siempre ( $y$ estaré) en Buenos Aires. ${ }^{14}$

(Borges 1974: 32)

Након поновног боравка породице Борхес у Европи (1923-1924), Хорхе Луис је објавио своју другу збирку Месеи, og йрекойуйа, састављену од 17 песама сачињених у ултраистичком маниру. У предговору из 1969. године, написаном приликом ревизије првобитног рукописа ове антологије, аутор истиче да је топографија Буенос Ајреса у збирци Месеи оg йрекойуйа „наглашена и јавна“ за разлику од упадљиво интимистичке топографије приказане у збирци Оgушевљење Буенос Ајресом (Borges 1974: 55). С друге стране, Борхес у обема збиркама користи уобичајене песничке симболе (ружа, југ, равница) да би нагласио локални колорит (Dadon Benseñor 2003: 3) као, на пример, у песми „Ули-

13 Гиљермо де Tope (Guillermo de Torre, 1900-1971), шпански песник, есејиста и књижевни критичар, сматра се једним од зачетника ултраизма у Шпанији; био је ожењен Борхесовом сестром Нором (Norah Borges).

14 „Овај град који сам веровао да је моја прошлост / представља моју будућност, моју садашњост; / године које сам проживео у Европи су привидне, / ја сам увек био (и бићу) у Буенос Ајресу.“ (Превела са шпанског Весна Дицков.) 
ца са ружичастим дућаном“("Calle con almacén rosado”) из збирке Месеи, og йрекойуйа:

Aquí otra vez la seguridad de la llanura en el horizonte y el terreno baldío que se deshace en yuyos y alambres y el almacén tan claro como la luna nueva de ayer tarde. Es familiar como un recuerdo la esquina con esos largos zócalos y la promesa de un patio. ¡Qué lindo atestiguarte, calle de siempre, ya que miraron tan pocas cosas mis días! Ya la luz raya el aire. Mis años recorrieron los caminos de la tierra y del agua $y$ sólo a vos te siento, calle dura y rosada. ${ }^{15}$

(Borges 1974: 57)

у којој је Буенос Ајрес као извор светлости симболично приказан не само као извор ауторовог свеколиког песничког надахнућа, већ и као место одакле црпе своју целокупну животну снагу, односно, као његово основно егзистенцијално упориште:

Mis años recorrieron los caminos de la tierra y del agua y sólo a; vos te siento, calle dura y rosada.

Pienso si tus paredes concibieron la aurora, almacén que en la punta de la noche eres claro.

15 „Ево опет на хоризонту / спокојство равнице / и утрина с травуљином и жицом / и дућан који светли / као синоћ млад месец. / Као успомена близак ми је овај дућан на ћошку / са дугим цоклама и обећањем дворишта. / Лепо је посведочити те, вечна улицо, / јер сам у свом животу видео тако мало ствари! / Већ светлост ваздух бразда. / Моје године су превалиле путеве земље и воде, / а само тебе осећам, мирна и ружичаста улицо." (Превео са шпанског Радивоје Константиновић.) (Борхес 1992: 136) 
Буенос Ајрес у поезији Хорхеа Луиса Борхеса...

Pienso y se me hace voz ante las casas

la confesión de mi pobreza:

no he mirado los ríos ni la mar ni la sierra,

pero intimó conmigo la luz de Buenos Aires

y yo forjo los versos de mi vida y mi muerte con esa

luz de calle.

Calle grande y sufrida,

eres la única música de que sabe mi vida. ${ }^{16}$

(Borges 1974: 57)

Пампа, која окружује главни град Аргентине са северне, западне и јужне стране, представља за Борхеса, у подједнакој мери као и сиромашне, радничке четврти на периферији Буенос Ајреса, снажну емотивну спону са поднебљем где је поникао, те у песми „На хоризонту једног предграђа“ динамичном променом ритма наглашава њен изузетан значај:

Pampa:

Yo diviso tu anchura que ahonda las afueras, yo me estoy desangrando en tus ponientes.

Pampa:

Yo te oigo en las tenaces guitan as sentenciosas

$\mathrm{y}$ en altos benteveos y en el ruido cansado

16 „Моје године су превалиле путеве земље и воде, / а само тебе осећам, мирна и ружичаста улицо. / Мислим, можда су твоји зидови зачели зору, / дућане, што си читаву ноћ осветљен. / Размишљам и, пред овим кућама, налазим речи / да исповедим своје сиромаштво: / нисам гледао ни реке, ни море, ни планину, / већ стекох поверење светлости Буенос Аjpeca / и исковах стихове свог живота и смрти / од те светлости уличне. / Велика и напаћена улицо, / ти си једина музика за коју мој живот зна.“ (Превео са шпанског Радивоје Константиновић.) (Борхес 1992: 136) 
de los carros de pasto que vienen del verano.

Pampa:

El ámbito de un patio colorado me basta

para sentirte mía.

Pampa:

Yo sé que te desgarran

surco y callejones y el viento que te cambia.

Pampa sufrida y macha que ya estás en los cielos, no sé si eres la muerte. Sé que estás en mi pecho. ${ }^{17}$

(Borges 1974: 58)

Трећа Борхесова збирка Свеска Светии Марӣин, састављена од 9 песама, одражава ауторову стилску приврженост поетици ултраизма (необичне метафоpe, занемаривање риме, присуство елемената ликовне уметности) и тематици везаној за родни град. У једној од својих најпознатијих песама „Митско оснивање Буенос Ajpeca" ("La fundación mítica de Buenos Aires"), Борхес везује оснивање аргентинске престонице за локалитете који су обележили његово детињство и књижевно стваралаштво (породична кућа, четврт Палермо и околне улице), а не за хипотетичко место поменуто у историјским списима, повезавши на тај начин историјско сећање на град са сопственом урбаном митоло-

17 „Пампа, / осећам твоју ширину која продубљује предграђа, / крв ми отиче на твојим заласцима. // Пампа, чујем те у упорним мисаоним гитарама / и високим царићима и уморној шкрипи / кола̂ са сеном која пристижу из лета. // Пампа, / довољно ми је да видим пространство црвеног дворишта / па да осетим да си моја. // Пампа, / знам да те раздиру / бразде и излокани друмови и ветар мења. / Пампа, напаћена и мужевна што си већ на небу. / Не знам јеси ли смрт. Знам да си ми у грудима." (Превео са шпанског Радивоје Константиновић.) (Борхес 1992: 137) 
гијом (Mendiola Oñate 2005: 178):

¿Y fue por este río de sueñera y de barro que las proas vinieron a fundarme la patria? Irían a los tumbos los barquitos pintados entre los camalotes de la corriente zaina.

Pensando bien la cosa, supondremos que él río era azulejo entonces como oriundo del cielo con su estrellita roja para marcar el sitio en que ayunó Juan Díaz y los indios comieron.

Lo cierto es que mil hombres y otros mil arribaron por un mar que tenía cinco lunas de anchura y aun estaba poblado de sirenas y endriagos y de piedras imanes que enloquecen la brújula.

Prendieron unos ranchos trémulos en la costa, durmieron extrañados. Dicen que en el Riachuelo, pero son embelecos fraguados en la Boca. Fue una manzana entera y en mi barrio: en Palermo.

Una manzana entera pero en mita del campo expuesta a las auroras y lluvias y suestadas. La manzana pareja que persiste en mi barrio: Guatemala, Serrano, Paraguay, Gurruchaga.

Un almacén rosado como revés de naipe brilló y en la trastienda conversaron un truco; el almacén rosado floreció en un compadre, ya patrón de la esquina, ya resentido y duro.

El primer organito salvaba el horizonte con su achacoso porte, su habanera y su gringo. 
El corralón seguro ya opinaba YRIGOYEN, algún piano mandaba tangos de Saborido.

Una cigarrería sahumó como una rosa

el desierto. La tarde se había ahondado en ayeres, los hombres compartieron un pasado ilusorio. Sólo faltó una cosa: la vereda de enfrente.

A mí se me hace cuento que empezó Buenos Aires: La juzgo tan eterna como el agua y el aire. ${ }^{18}$

(Borges 1974: 81)

18 „Зар по овој реци сненој и блатној / да ми оснују отаџбину дођоше прамци? / Шарени чунови ишли су по таласима / између пловећег биља тамне матице. // Претпоставићемо, дакле, после зрелог размишљања, / да је река била модрикаста као да на небу извире, / а мала црвена звезда означавала место / на коме је Хуан Дијас постио, а Индијанци мрсили. // Извесно је да хиљаду људи и других хиљаду приспело / по мору пет уштапа широком, / пуном немани и сирена / и магнетних стена што залуђују бусолу. // Подигоше неколико јадних колиба на обали, / заспаше као странци. Кажу да је то било у Ријачуелу, / но то су измишљотине са Ушћа. / У ствари читава скупина кућа, и то у мојој четврти, у Палерму. // Једна скупина кућа али усред поља / изложена зорама, кишама и ветровима. / У мојој четврти та скупина још постоји. / Улице Гватемала, Серано, Парагвај, Гуручага. // Ружичасти дућан је као наличје карте / засијао, у задњој собици загаламили су уз труко, / ружичасти дућан се закитио кавгаџијом / што се прси на углу, осион и груб. // Први вергл је хоризонт поздравио / својим варљивим расположењем, хабанером, свирком неразговетном. / Цело стовариште је одобравало: Иригојен, // далеки клавир свирао је Саборидова танга. // Трафика је замирисала као ружа / пустињом. У јучерашњици вече се сакрило, / нестварну прошлост поделили су људи. / Недостајало је само једно: плочник на другој страни. // Причају ми да је Буенос Ајрес настао: / сматрам га вечитим као воду и ваздух.“ (Превео са шпанског Радивоје Константиновић.) (Борхес 1992: 138-139) 
Буенос Ајрес није само једна од конвенционалних тема у Борхесовој поезији, као што су самоћа или љубав, већ се односи на нешто много дубље, стварније и фантастично, имплицирајући један посве засебан универзум, односно, „његов универзум“; при томе, треба имати у виду да је Борхес у суштини био човек прошлости, који је градио свој поетски свет од успомена, а да његова прва збирка, са песмама које превазилазе оквире дескриптивности и одражавају сугестивним тоном ауторов филозофски став, представља, у ствари, слику Буенос Ajpeca (Dante Cincotta 2005: 233-234). Градски пејзаж опеван у Борхесовој „буеносајреској трилогији" (Оgушевљене Буенос Ајресом, Месеи оg ире-

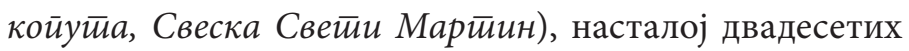
година прошлог века, одликује стилски минимализам: слике дворишта, прагова, дућана, ћупова, тремова, ћошкова и уличица нижу се у меланхоличним, интимистичким стиховима; избор и обрада мотива никада нису случајни, а њихово скривено значење изискује подробно тумачење (Dadon Benseñor 2003: 4). У овим стиховима приметан је утицај креолизма, сматра Висенте Сервера Салинас (Cervera Salinas 1992: 74), почев од опеваних локација (четврти Палермо, Север и Југ; гробља Реколета и Ћакарита), историјских елемената (митско оснивање Буенос Ајреса, Росасова диктатура, смрт генерала Кироге), географских тема (похвала пампи) до стилских ефеката који се постижу коришћењем колоквијалног говора (специфични креолски изрази и синтаксичке конструкције). Хорхе Луис Борхес се сматра првим правим урбаним песником Хиспанске Америке, који својим формалним и стилским иновацијама, првенствено израженим кроз интелектуални процес асоцирања неуобичајених елемената, пружа читаоцима најразличитије слике родног града, настале у потпуно- 
сти као субјективни, ментални одраз објективне стварности (Дицков 2016: 51).

Прва антологија Борхесове поезије на српском језику изашла је 1982. године под насловом Изабране йесме у издању Српске књижевне задруге; Радивоје Константиновић је одабрао и превео са шпанског језика све Борхесове песме (94) из овог избора, за шта је добио награду Удружења књижевних преводилаца Србије „Милош Н. Ђурић“ (Дицков 2014: 42-43). Поред Изабраних иесама, Константиновић је превео 1985. године Борхесову збирку песама Шифра (La cifra, 1981), а потом је приредио три антологије посвећене Борхесовом целокупном књижевном стваралаштву (Проза; Поезија; Есеј, 1986; Изабрана йроза и йоезија, 1992; Изабрана gела: Проза, ӣоезија, есеј, 1995). Захваљујући изузетној посвећености Радивоја Константиновића у рецепцији литерарног дела Хорхеа Луиса Борхеса на српском језичком подручју, наши читаоци су имали прилику да се подробно упознају са песништвом овог хиспаноамеричког аутора и да самостално откривају и спознају његов однос према родном граду, Буенос Ајресу.

\section{Извори и литература}

Борхес, Хорхе Луис. Изабрана ӣроза и йоезија. Приредио Радивоје Константиновић. Превели са шпанског Радивоје Константиновић, Драгана Бајић и Марина Љујић. Београд: Просвета, 1992. Штампано.

Borges, Jorge Luis. Obras completas (1923-1972). Buenos Aires: Emecé Editores, 1974. Impreso.

Videla, Gloria. El ultraísmo. Estudios sobre movimientos poéticos de vanguardia en España. Madrid: Gredos, 1971. Impreso.

Dadon Benseñor, José R., "Borges, los espacios geográficos y los espacios literarios”, Scripta Nova. Revista electrónica de 
geografía y ciencias sociales, VII.145 (15.7.2003), 1-15.

Web. 23.3.2018.

Dante Cincotta, Héctor, "La poesía de Jorge Luis Borges", Revista de Humanidades: Tecnológico de Monterrey, 19 (2005), 233246. Web. 05.11.2017.

Дицков, Весна. „Песничко стваралаштво Хорхеа Луиса Борхеса у Србији“, у Србија између исӣока и зайаgа, књ. 3, Кюижев-

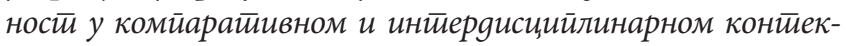
$c \bar{u} y$. Београд: Филолошки факултет, 2014, 41-59. Штампано.

Дицков, Весна. Хисйаноамеричка кюижевносии: оg йосиммоgернизма gо йосӣбума. Београд: Филолошки факултет, 2016, 49-52. Штампано.

Zito, Carlos Alberto. "El Buenos Aires de Borges", Variaciones Borges, 8 (1999), 108-120. Web. 07.11.2017.

Zonana, Víctor Gustavo. "Jorge Luis Borges: su concepción de la metáfora en la década del '20", Revista de Literaturas Modernas, 29 (1999), 295-320. Web. 29.3.2018.

Mendiola Oñate, Pedro. Buenos Aires entre dos calles: breve panorama de la vanguardia poética argentina. Alicante: Biblioteca Virtual Miguel de Cervantes, 2005, 175-190. Web. 15.3.2018.

Pavlović-Samurović, Ljiljana. Leksikon hispanoameričke književnosti. Beograd: Savremena administracija, 1993, 316326. Штампано.

Cervera Salinas, Vicente. La poesía de Jorge Luis Borges: Historia de una eternidad. Universidad de Murcia, 1992. Web. 03.4.2018. 
Vesna Dickov

\author{
BUENOS AIRES IN THE POETRY \\ OF JORGE LUIS BORGES: \\ “THE BUENOS AIRES TRILOGY” (1923-1929)
}

\title{
Summary
}

This paper deals with the interpretation of the presence of Buenos Aires in Borges's early poetical works, ie. "The Buenos Aires Trilogy" which is composed of the first three collection of poems written by Jorge Luis Borges: Passion for Buenos Aires (1923), Moon Across the Way (1925) and San Martín Copybook (1929). The location and significance of the capital city of Argentina, its suburbs, streets, squares and parks in the aforementioned collections are examined in order to determine the role of Buenos Aires in artistic identification of Jorge Luis Borges as an extremely urban poet. The landscape painted in "The Buenos Aires Trilogy" features stylistic minimalism: images of hidden courtyards, small shops, porches, corners and streets are indicated in melancholic, intimistic verses; selection and processing of motives are never random, and their hidden meaning requires detailed interpretation. Borges is considered to be the first true urban poet of Hispanic America, who through his formal and stylistic innovations, primarily expressed through the intellectual process of associating unusual elements, gives readers the most diverse picture of the hometown, arising entirely as a subjective, mental reflection of objective reality. Thanks to the outstanding dedication of Radivoje Konstantinović who translated most of Borges's poems into the Serbian language, our readers had the opportunity to get acquainted with the poetry of this Hispanic author and to discover the relationship of Borges to his hometown, Buenos Aires.

Key words: Hyspanic American Poetry, Jorge Luis Borges, Buenos Aires, city, ultraist movement. 